DOI: 10.46340/eppd.2020.7.2.12

Pavlo Bohutsky, PhD in Law

ORCID ID: https://orcid.org/0000-0003-3537-6991

Scientific Research Institute of Informatics and Law of the National Academy

of Legal Sciences of Ukraine

\title{
HUMAN SUBJECTIVITY IN NATIONAL SECURITY LAW
}

The subjectivity of a person in national security law is determined by its legal status and its implementation in legal strategic communications. The national security law substantiates the legal status of a person, defines the conditions and enforces human rights and fundamental freedoms in accordance with the provisions of the Universal Declaration of Human Rights, defines legal obligations that correspond to the relevant rights and are consistent with the activities of the state and society for national security. Crucial in legal strategic communications of national security is the protection of the human right to security, as a natural and inalienable right. The right to security in the concept of human subjectivity in national security law has an axiomatic meaning, is essentially a legal postulate, needs no proof, should be regarded by social actors as the initial formula of the human-centered legal reality. Human subjectivity in national security law presupposes the unity of rights, freedoms, legitimate interests and legal obligations that hold a certain balance in the legal status of a person, which is based on the provisions of the Convention for the Protection of Human Rights and Fundamental Freedoms.

Keywords: National Security Law, Legal Strategic Communications, Human Subjectivity, Human Legal Status, Right to Security.

Formulation of the problem. Human subjectivity in national security law is manifested through the determination of a person's legal status and its implementation in the legal strategic communications of national security. However, the nature of a status of legal communication actually testifies to the transition of social relations, certain acts of interaction of social entities in the legal, the acquisition of the state of legal completeness in the complex process of legal communications with human participation, which requires appropriate scientific substantiation.

The purpose of the article is to establish and reveal the laws and peculiarities of human subjectivity in the law of national security, in legal strategic communications of national security with the definition of status features, their approval on the basis of human-centrism.

State of the study of the problem is characterized by the development of the problem of human subjectivity through the disclosure of its legal status in the works of P. Rabinovych, M. Kozyubra, S. Maksimov, S. Golovatyi, D. Gudima, N. Ortynska and other scientists, but indicates the lack of thorough research problems of human subjectivity in national security law, which emphasizes the particular relevance of the article.

Legal status and subjectivity of a person in national security law

Among the legal communications, among the many relationships in the society, the most important ones are those directly related to the person, which determine the legal status of the person and give the opportunity to realize such status in the law of national security.

If at the heart of the world order is, in practice, the authoritative conceptual opinion of Hersh Lauterpacht, man, as the basic unit of all law ${ }^{1}$, then in national order and national law, this provision must be maintained and enforced. That is why, despite the established approaches to defining legal communications, it is more important to understand such communications as the interactions and relationships of certain legal status carriers.

The problem of subjectivity and legal status of a person has not accidentally occupied a prominent place in the research of scientists. There is no need to focus on positions regarding the term of a person's

${ }^{1}$ Lauterpacht, H. (1943). The Law of Nations, the Law of Nature and the Rights of Man, in Problems of Peace and War. Papers Read before the Society in the Year 1943, ed. British Institute of International and Comparative Law, Transactions of the Grotius Society, 29, 31. 
legal status, since we are unable to identify a section of conventionality that would allow us to come to a common opinion and to draw a generalized conclusion about the terminological unity and content of a person's legal status. The etymology of legal status provides more complete information and relevant material for legal doctrine and practice. Legal status (from the Latin status - position) is traditionally understood in jurisprudence as a set of rights and freedoms of individuals and legal entities ${ }^{1}$. However, this is too narrow an understanding of the legal status, especially when applied to a person's legal status. It is necessary to agree with the stated and substantiated position that "legal status cannot be based solely on legislative norms governing rights and obligations; it is a broader system which in a democratic society must contain the whole complex of legal phenomena in order to guarantee a high level of protection and the importance of person" 2 . The legal status of a person covers all the permanent and necessary legal characteristics of a person as a legal person, distinguishes the legal person among other subjects of law, determines the constant parameters of social communications, relationships between individuals and, more importantly - between a person and all social actors who have the ability to influence human being in space and time. The legalization of a person, the acquisition of legal characteristics, is carried out through the appropriate legal status. The legal status of a person is not the result of the activities of any social actor, including the state, because no one gives the right to life to a person, other rights and fundamental freedoms, no one defines a person's protected interests. D. Gudyma's substantive conclusions are quite correct in this regard: "A human being is a human individual who, in view of his biological nature, has inherent inborn legal qualities (natural, inalienable, fundamental rights), which is the most important component of general social law» ${ }^{3}$. At the same time, the scientist's opinions regarding the differences between the different concepts of legal person ${ }^{4}$ are controversial, since in such a case it is necessary to go to a different level of discussion - legal personality, legal individual, citizen's legalization, etc. ${ }^{5}$, which is difficult to agree with due to some scholasticism. The solution to this not only ideological issue is to understand the legal status of a person as a legal person, which must be recognized by all social actors, and the content of the state should be, again worth emphasizing, not only the recognition of this fact, but also the focus on the protection of the legal human status.

However, in practice, the legal status of a person is constantly influenced by social actors, among which the influence of the state is of particular importance because of its capacity to legislate and to enforce it. It should be noted that the legal status of a particular person can be subjected to certain destructive actions not only from the state, but also from other participants of social communications, which are both the society in the person of its numerous entities and individual social actors. It is important that as a result of such subversive, destructive actions, the content of the legal status of the person remains unchanged, but certain obstacles to the realization of human rights, freedoms and legitimate interests of the person may be created, which in the historical aspect provides many examples for scientific analysis, and in practice it is many reasons for the decision enforcement issues. In such cases, the importance of maintaining the stability of the legal status of a person, his or her compliance with all the characteristics of a legal person is an extremely pressing issue, which is solved from the standpoint of national security. That is why national security is not just the protection of the most important national interests ${ }^{6}$; it is the stability and inviolability of a person's legal status, the legal justification for why we find it in national security law.

The legal status of a person covers all competences that are in constant motion and in constant interaction with legal obligations. Actually, such is the legal status of any social actor, an active social subject, but the legal status of the person most clearly demonstrates the peculiarities of interaction and interconnection of powers and responsibilities. National security creates all the necessary and sufficient conditions for the formation of a person's legal status in the form and content that give every reason to conclude that there is a virtually

\footnotetext{
${ }^{1}$ Шемшученко, Ю.С. (ред.) (2003). Юридична енциклопедія: в 6 m. Київ: «Укр.енцикл.», T. 5 , 44.

${ }^{2}$ Ортинська, Н.В. (2016). Правовий статус людини: до проблем теоретичного розуміння. Право $і$ безпека, 3(62), 30.

${ }^{3}$ Гудима, Д.А. (2005). Людинорозуміння у правовій науці (до характеристики сучасного поняттєвого апарату). Проблеми філософії права, III, 1-2, 260.

${ }^{4}$ Гудима, Д.А. (2005). Людинорозуміння у правовій науці (до характеристики сучасного поняттєвого апарату). Проблеми філософії права, III, 1-2, 260.

${ }^{5}$ Гудима, Д.А. (2009). Людина правова та юридична: спроба антрополого-герменевтичного аналізу. Актуальні проблеми держави і права, 1, 276-283.

6 Закон про національну безпеку Украйни 2018 (Верховна Рада України). Офіиійний веб-сайт Верховної Ради

Украӥни. <http://zakon.rada.gov.ua/laws/show/2469-19>.
} 
insurmountable barrier to the realization of possible and real threats to life, which is primarily concerned with a particular person, personality, but as a consequence of creating threats to the existence of society, humanity. This conclusion is based not only on the paradigmatic importance of the human legal status for national security, but also on the basis of the formation and real existence of the human legal status solely in the context of security directly generated by national security. Characteristics of a person's legal status in this context are to ensure that the person's protection status is in conformity with rights, legitimate interests, obligations, and, last but not least, guarantees of the exercise of rights and legitimate interests. M. Kozyubra, referring to the Institute for Human Rights, states that "it is with the help of this institute that a person joins the material and spiritual goods of society, the mechanisms of power, the legitimate forms of expression of self-interest and the realization of his own interests. The degree of perfection of the individual, his life and health, honor and dignity, integrity and security depend on the level of security of law. "The human dimension", after all, is a touchstone and the point of reference for any transformation that takes place in society" 1 .

National security as the protection of the individual, human content and purpose in legal strategic communications substantiates the legal status of the person forms the regime that defines forms and structures the legal status of the person.

The structure of a person's legal status is relatively unchanged and is capable of qualitative updating only in a state of security, that is, protection against threats to human existence. We can think of human personality and assess a person's ability to have rights, obligations and responsibilities only in the event of threats that may lead to the physical destruction of a person or to a significant restriction on the realization of a person's inherent capacity to be the subject of legal strategic communications and legal communications in general. The limitation of the physical condition of a person leads to a restriction of legal personality in the area where such a restriction occurred, and consequently, of legal personality as a whole. The method of such restriction is important for the assessment of danger, but it is not decisive from the standpoint of law, since for the existence of the right of a particular person (it is not a subjective right, but a right in its general or social sense), the ability of a person to perceive is important, to understand the law, to realize it in such a way that it allows a particular person to be part of the legal reality with all the qualities of a legal person. The law that has happened or the law that comes directly depends on the conditions of human existence. In a state of danger, in the state of actual realization of threats to national security, a person may be put in a situation where the right is lost. This process occurs at the same time as the implementation of those socially dangerous acts that involve limitations of the spatial, temporal, physical being of a person, which significantly limit the necessary characteristics of a person's life and narrow or even destroy the possibilities of conscious attitude to law.

Subjective rights, freedoms and legal obligations, legitimate interests in the legal status of a person are directly dependent on the resolution of security issues and at the same time determined by the level of security of human life, the state of protection of national interests. It is important the connection between this section of the legal status of a person and national interests. It is a matter of priority for certain groups of rights, freedoms, legitimate interests on the one hand, and legal obligations on the other for securing and pursuing national interests. It is precisely in the area of national interests that some subjective rights, freedoms and legitimate interests may be narrowed and legal responsibilities strengthened, as a process necessary to ensure national security. However, this approach, despite its rationality and practicality, contains a certain error, which must be identified and declared as an exception to the general rule, since a successful solution to the problem of national security is possible only in the state of deployment of a person's legal status, his subjective rights, freedoms and legitimate interests. Another thing is that in the face of real threats to national security, which are manifested including threats to human life, it is possible to temporarily restrict the rights, freedoms of the person, which should be exercised legitimately, on a legal basis and without prejudice to the basic task of preserving and deploying legal status of a person, but only to ensure that the task is solved under the conditions of the relevant legal regime.

In the structure of a person's legal status, the most important is to connection the guarantees of human rights, freedoms and legitimate interests with national security. Outside the protection of human beings, beyond the protection of human life, the issue of guarantees of human rights, freedoms and legitimate interests of a person can neither be the subject of discourse nor the subject of a practical decision to preserve the integrity of a person's legal status.

Therefore, we proceed to the level of generalization and justification of the very fact of a person's legal status, the formation and existence of which depends entirely on the security status, which is, on ensuring

${ }^{1}$ Козюбра, М.I. (2010). Права людини і верховенство права. Право Украӥни, 2, 24. 
national security, namely the protection of national interests, which in this case appear to be a concentrated expression of rights, freedoms and legitimate human interests.

National security law reveals all the features of a systemic value-normative and institutional formation, which defines the necessary and sufficient guarantees of a person's legal status, substantiating the very fact of its existence within the national legal system and implementation in legal strategic communications. In order to confirm or refute this important opinion in the context of research, we must go beyond the national legal system, which is quite understandable. The legal status of a person is based on the provisions of the Universal Declaration of Human Rights, adopted and proclaimed by UN General Assembly resolution 217 A (III) on 10 December $1948^{1}$. It is worth paying attention to the provisions of Art. 28 of the Universal Declaration of Human Rights, according to which everyone has the right to a social and international order in which the rights and freedoms set forth in this Declaration, can be fully realized. It is certainly a state of security that has national and international dimensions and guarantees the implementation of human rights and freedoms. And in the context of the content of the legal status, the provisions of Article 29 of the Universal Declaration of Human Rights are important, according to which everyone has duties to the community in which alone the free and full development of his personality is possible; in the exercise of his rights and freedoms, everyone shall be subject only to such limitations as are determined by law solely for the purpose of securing due recognition and respect for the rights and freedoms of others and of meeting the just requirements of morality, public order and the general welfare in a democratic society ${ }^{2}$. The analysis of the significance and nature of the Universal Declaration of Human Rights was made possible by S.I. Maximov make the important conclusion that "on the one hand, their conceptual framework is based on the achievement of the classical philosophy of law, and on the other, in substantiating the unconditional nature of human rights, appeals to the new for the twentieth century phenomenon which is the totalitarianism, as the danger that threatens the civilized existence of mankind. Thus, in essence, the Universal Declaration of Human Rights 1948 is an anti-totalitarian legal veto. It codifies the condemnation of Hitler's "new order" by the world community and the repentance of that order. Each signatory state accedes to the worldwide denial of the repetition of totalitarianism by providing a set of guarantees of personal autonomy (religious, ethical, intellectual, civil, economic)"3.

Legal strategic communications between a person, a citizen and state based on their status value and provide for mutual rights and obligations, mutual responsibility. In this connection, N.M. Onishchenko rightly points out that "nowadays, responsibility to a person is beginning, albeit slowly, to become more or less real in nature ... The establishment of norms of state responsibility before a citizen is a testament to the recognition of the state priority of the rights and freedoms of a citizen over other values in society"4.

However, there is some important clause, according to which restrictions when it comes to human rights, the important is to limit any scope for free discretion of the state, its agencies and officials, and the main principle that must act in such cases is the principle of proportionality. The content of this principle is manifested in the fact that the general interest governed by the state cannot be such as to suppress the freedom of the individual; the balance, the proportionality of the public (in particular, the state) interests and the interests of the individual accompanies and determines the process of restricting human rights ${ }^{5}$.

In the legal status of a person, legal obligations confirm the socially necessary behavior of a person. In a sense, a person's legal responsibilities are his or her legal obligations in social communications, which correspond to the corresponding rights of other participants in social communications. Such a legitimate need is manifested in rules of law, in publicly recognized and publicly enforced rules of conduct that are universally recognized. In this regard, characterizing legal obligations as social obligations, P.M. Rabinovych notes:

\footnotetext{
1 Загальна декларація прав людини, прийнята і проголошена резолюцією 217 А (III) Генеральної Асамблеї ООН від 10 грудня 1948 року. Офіиійний веб-сайт Верховної Ради Украӥни.

$<$ https://zakon.rada.gov.ua/laws/show/995_015>.

2 Загальна декларація прав людини, прийнята і проголошена резолюцією 217 А (III) Генеральної Асамблеї ООН від 10 грудня 1948 року. Офіиійний веб-сайт Верховної Ради Украӥни.

$<$ https://zakon.rada.gov.ua/laws/show/995_015>.

${ }^{3}$ Максимов, С. (2009). Необхідність філософського обгрунтування прав людини. Вісник академії правових наук Украӥни, 1(56), 33.

${ }^{4}$ Петришина, О.В. (заг. ред.) (2013). Правова доктрина України: у 5 т. T.1: Загальнотеоретична та історична юриспруденияія. Харків: Право, 343.

${ }^{5}$ Козюбра, М.I. (заг. ред.) (2015). Загальна теорія права: підручник. Київ: Ваіте, 60.
} 
"the universal social duty of a person is the need for certain behavior, which is objectively determined by the specific historical needs of the existence and development of other people, the nation, the people, his social strata and all humanity"'.

Legal responsibilities in their social significance consolidate the efforts of all social actors to ensure the balance, stability of legal strategic communications, the realization of human rights and freedoms, the achievement of social actors, first and foremost by a person, identified and supported in the public interest, among which national interests are of paramount importance to resolve security issues. That is why national security law is seen as a systemic integrity that demonstrates the unity of human rights, freedoms, legitimate interests and legal responsibilities, as well as other social actors, which are the state, society in the person of certain institutions. Such unity is constant in content, but has dynamic characteristics in legal strategic communications, manifests itself at different levels, in various forms, in many cases transforms, acquires those social characteristics that correspond to the real state of human life security and the existence of society and the state.

The unity of rights, freedoms, legitimate interests and legal obligations in a person's legal status holds a certain balance based on the provisions of the Convention for the Protection of Human Rights and Fundamental Freedoms ${ }^{2}$. This is emphasized by scientists at the L'viv Laboratory for Human and Citizen Rights, noting that "the limits of the exercise of rights and freedoms must meet international standards. At the same time, a fair balance of human rights and freedoms and public interests must be ensured" ${ }^{3}$. It is important that the principle enshrined in the Convention for the Protection of Human Rights and Fundamental Freedoms ensures that the balance of rights, freedoms, legitimate interests, human legal obligations, and public interests is asserted, and that it is possible to affirm that international and, therefore, national security are safeguarded. The stated principle is the principle of dependence of the state on the legal status of a person, its filling in the national legislation with the relevant norms and ensuring the states in practice in legal strategic communications. This unites the democratic states of Europe, as one of the means of achieving this is to safeguard and promote human rights and fundamental freedoms, and the fundamental freedoms constitute the foundations of justice and peace throughout the world and are best served, on the one hand, through effective political democracy and, on the other hand, by a shared understanding and respect for the human rights on which they depend ${ }^{4}$. The dependence of states on understanding and respect for human rights is evidence of the real state of national security, when the responsibility of a person to society and the state can in no way be greater than the responsibility of society and the state to the same person. However, a prerequisite state recognition of the legal status of human determining factor of state power is a human right to safety that researchers, including German scientist JD Rainer Arnold, include the fundamental rights and recognize the task of the state to create and maintain security ${ }^{5}$.

The right to human security can be regarded as an absolute right, but with some caveat. In this case, it is important not the mere obligation of an indefinite range of subjects not to violate a person's right to security, which is usually of paramount importance, but the duty of the state and society to ensure the human right to security. The right to demand in legal strategic communications not to violate the safe conditions of human activity needs to be provided and protected, which is within the competence of the relevant institutions of the state. It is worth agreeing with the position of S.O. Slipchenko, who believes that "the use of the literal meaning of the word 'absolute' to unite a group of completely different rights by nature and those that already have a special name in the theory of law, is not entirely justified"6. The right to security in the legal status of a person should be regarded as a fundamental human right, which determines its assignment to fundamental

\footnotetext{
${ }^{1}$ Рабінович, П.М. (2001). Основи загальної теорії права та держави. Київ: Атіка, 18.

${ }^{2}$ Конвенція про захист прав людини і основоположних свобод. Офіційний веб-сайт Верховної Ради Украйни. $<$ https://zakon.rada.gov.ua/laws/show/995_004>.

${ }^{3}$ Рабінович, П. (2014). Конституційно-правовий статус людини і громадянина: можливості оптимізації. Вісник Національної академії правових наук України, 1 (76), 25.

${ }^{4}$ Конвенція про захист прав людини і основоположних свобод. Офіційний веб-сайт Верховної Ради Украӥни. $<$ https://zakon.rada.gov.ua/laws/show/995_004>.

${ }^{5}$ Права людини і національна безпека: роль органу конституиійної юрисдикиії: міжнародна конференція з нагоди Дня Конституції України. <http://www.ccu.gov.ua/novyna/prava-lyudyny-i-nacionalna-bezpeka-rolorganu-konstytuciynoyi-yurysdykciyi-mizhnarodna-1>.

${ }^{6}$ Сліпченко, С.О. (2014). Огляд теоретичних підходів до розуміння абсолютного права. Право та інноваџійне суспільство, 2 (3). <http://apir.org.ua/wp-content/uploads/2014/12/Slipchenko.pdf>.
} 
rights, which in this sense "is the basis for the existence of a person as such, the development of his personality, and their recognition and security (non-interference by the state) is absolutely necessary for the state..."1

The ability of the state to assure the human right to security, and therefore to safe living conditions and well-being, attests to the state's ability to exercise external and internal functions in general, which undoubtedly confirms the sovereignty of the state in legal strategic communications of international and national importance. The human right to security is not defined in the Constitution of Ukraine or in any of the laws that contain provisions on the legal status of a person. At the same time, there is no doctrinal definition of the right to security, which would become universally recognized. This situation is explained by the fact that the human right to security is a natural, objective right, security competences are present in all human rights and fundamental freedoms, do not require any declaration by public authorities, but must be protected and guaranteed. The human right to security is a legal sign of the inviolability of the legal status of a person having social, economic, political, military characteristics based primarily on the provisions of the Constitution. Therefore, it is possible to define a certain constitutional and legal mechanism for securing the right to personal security, which is defined as "as a system of interrelated, interacting factors, means and preconditions by which, in the conditions of compliance with law, appropriate legal and factual opportunities for full implementation are created, everyone's rights to personal security are eliminated by negative conditions that could harm their practical implementation"2.

Human security is always individual, personal and this is the most important interest of a person who objectively creates national interests.

In US legal doctrine, the right to human security is disclosed precisely for the implementation of personal security. Thus, in John Bouvier's Law Dictionary as early as 1839 and later, it defines the concept of personal security as: "The legal and uninterrupted enjoyment of a man of his life, his body, his health and his reputation," "the lawful and unbroken possession of man by his life, his body, his health and his reputation. In this sense, the right to personal security has the meaning of a subjective right and is implemented both in legal relationships, where the rights to personal security correspond to the obligations of other parties to the relationship to abstain from actions that violate that right, and in legal strategic communications of national security.

The right to human security is much larger than the scope of competences and involves the presence of a person not only in specific (relative) legal relationships, which solve certain security issues of his life, but also absolute legal relationships, in those legal strategic communications where the main participant and moderator of the person security is represented by the state in the person of the relevant institutions. It is this peculiarity of human security that scientists draw attention to, and point out that "a legally formalized expression of a person's security is a person's right to security, under which it is expedient to understand the legal capacity of a person as a subject of the right to maintain his or her state of safe life in the form of secured and protected by the state to self-fulfillment by the individual of their vital needs and diverse interests." ${ }^{4}$. In the end, it seems to be true that in understanding the human right to safety, the focus is on the ability to preserve and maintain a safe state of human life; it is this human opportunity that other human rights and fundamental freedoms contain, and the state and, to a certain extent, society, have a duty to ensure human security and to guarantee its inalienable right to security.

Conclusion. Human subjectivity in national security law is manifested in the strategic legal communications of national security through the realization of a legal status, which determines the rights and fundamental freedoms of a person to which certain obligations are fulfilled. The right to security in the concept of human subjectivity in national security law has an axiomatic meaning, is essentially a legal postulate, needs no proof, should be regarded by social actors as the initial formula of the human-centered legal reality. At the same time, the right to security is an institution of national security law, and in this way, the right of national security has the ability and opportunity to justify a person's legal status, to realize a social purpose with regard to its security and protection in legal strategic communications of national security.

\footnotetext{
${ }^{1}$ Цвік, М.В., Петришин, О.В. (ред.) (2009). Загальна теорія держави і права: підручник. Харків: Право, 455.

${ }^{2}$ Боднар, О.Б. (2011). Конституційні гарантії особистої безпеки в Україні: автореф. дис. ... канд. юрид. наук. Київ, 17-18.

${ }^{3}$ Bouvier, J. (1856). A Law Dictionary, Adapted to the Constitution and Laws of the United States.

$<$ https://legal-dictionary.the free dictionary.com/Personal+security $>$.

${ }^{4}$ Колоткина, О.А. (2015). Право личности на безопасность: понятие и механизмы обеспечения в РФ

(теоретико-правовое исследование): дис. .. канд. юрид. наук. Саратов, 61-73.
} 


\section{References:}

1. Bodnar, O.B. (2011). Konstytutsiini harantii osobystoi bezpeky v Ukraini: avtoref. dys. ... kand. yuryd. nauk [Constitutional guarantees of personal security in Ukraine: abstract. thesis. ... PhD of Law]. Kyiv. [in Ukrainian].

2. Hudyma, D.A. (2005). Liudynorozuminnia u pravovii nautsi (do kharakterystyky suchasnoho poniattievoho aparatu) [Human understanding in legal science (to the characteristic of the modern conceptual apparatus)]. Problemy filosofii prava [Problems of the philosophy of law], vol. III, no. 1-2, 260. [in Ukrainian].

3. Hudyma, D.A. (2009). Liudyna pravova ta yurydychna: sproba antropoloho-hermenevtychnoho analizu [Man law and legal: an attempt anthropological, hermeneutical analysis]. Aktualni problemy derzhavy i prava [Actual problems of the state and law], no. 1, 276-283. [in Ukrainian].

4. Zahalna deklaratsiia prav liudyny, pryiniata i proholoshena rezoliutsiieiu 217 A (III) Heneralnoi Asamblei OON vid 10 hrudnia 1948 roku [Universal Declaration of Human Rights, adopted and proclaimed by UN General Assembly resolution 217 A (III) of 10 December 1948]. Ofitsiinyi veb-sait Verkhovnoi Rady Ukrainy [The official website of the Verkhovna Rada of Ukraine]. <https://zakon.rada.gov.ua/laws/show/995_015>. [in Ukrainian].

5. Zakon pro natsionalnu bezpeku Ukrainy 2018 [Law on National Security of Ukraine] (Verkhovna Rada Ukrainy) [Verkhovna Rada of Ukraine]. Ofitsiinyi veb-sait Verkhovnoi Rady Ukrainy [The official website of the Verkhovna Rada of Ukraine]. <http://zakon.rada.gov.ua/laws/show/2469-19>. [in Ukrainian].

6. Koziubra, M.I. (2010). Prava liudyny i verkhovenstvo prava [Human rights and the rule of law]. Pravo Ukrainy [Law of Ukraine], no. 2, 24. [in Ukrainian].

7. Koziubra, M.I. (ed.) (2015). Zahalna teoriia prava: pidruchnyk [General Theory of Law: A Textbook]. Kyiv: Vaite. [in Ukrainian].

8. Kolotkina, O.A. (2015). Pravo lichnosti na bezopasnost': ponjatie i mehanizmy obespechenija $v$ RF (teoretikopravovoe issledovanie): dis. .. kand. jurid. nauk [The right of an individual to safety: the concept and mechanisms of support in the Russian Federation (theoretical and legal research): thesis of PhD of Law]. Saratov. [in Russian].

9. Konventsiia pro zakhyst prav liudyny i osnovopolozhnykh svobod [Convention for the Protection of Human Rights and Fundamental Freedoms]. Ofitsiinyi veb-sait Verkhovnoi Rady Ukrainy [The official website of the Verkhovna Rada of Ukraine]. <https://zakon.rada.gov.ua/laws/show/995_004>. [in Ukrainian].

10. Maksymov, S. (2009). Neobkhidnist filosofskoho obhruntuvannia prav liudyny [The need for a philosophical justification for human rights]. Visnyk akademii pravovykh nauk Ukrainy [Bulletin of the Academy of Law Sciences of Ukraine], no. 1(56), 33. [in Ukrainian].

11. Ortynska, N.V. (2016). Pravovyi status liudyny: do problem teoretychnoho rozuminnia [Legal status of man: to the problems of theoretical understanding]. Pravo i bezpeka [Law and security], no. 3(62), 30. [in Ukrainian].

12. Petryshyna, O.V. (ed.) (2013). Pravova doktryna Ukrainy: u 5 t. [The legal doctrine of Ukraine: in 5 volumes]. T.1: Zahalnoteoretychna ta istorychna yurysprudentsiia [Vol.1: General Theoretical and Historical Jurisprudence]. Kharkiv: Pravo. [in Ukrainian].

13. Prava liudyny i natsionalna bezpeka: rol orhanu konstytutsiinoi yurysdyktsii: mizhnarodna konferentsiia $\mathrm{z}$ nahody Dnia Konstytutsii Ukrainy [Human rights and national security: the role of the body of constitutional jurisdiction: international conference on the Day of the Constitution of Ukraine]. <http:/www.ccu.gov.ua/novyna/pravalyudyny-i-nacionalna-bezpeka-rol-organu-konstytuciynoyi-yurysdykciyi-mizhnarodna-1>. [in Ukrainian].

14. Rabinovych, P. (2014). Konstytutsiino-pravovyi status liudyny i hromadianyna: mozhlyvosti optymizatsii [Constitutional and legal status of the person and the citizen: possibilities of optimization]. Visnyk Natsionalnoi akademii pravovykh nauk Ukrainy [Bulletin of the National Academy of Law of Ukraine], no. 1 (76), 25. [in Ukrainian].

15. Rabinovych, P.M. (2001). Osnovy zahalnoi teorii prava ta derzhavy [Fundamentals of the general theory of law and state]. Kyiv: Atika. [in Ukrainian].

16. Slipchenko, S.O. (2014). Ohliad teoretychnykh pidkhodiv do rozuminnia absoliutnoho prava [An overview of theoretical approaches to the understanding of absolute law]. Pravo ta innovatsiine suspilstvo [Law and Innovation Society], no. 2 (3). <http://apir.org.ua/wp-content/uploads/2014/12/Slipchenko.pdf>. [in Ukrainian].

17. Tsvik, M.V., Petryshyn, O.V. (ed.) (2009). Zahalna teoriia derzhavy i prava: pidruchnyk [General theory of state and law: a textbook]. Kharkiv: Pravo. [in Ukrainian].

18. Shemshuchenko, Yu.S. (ed.) (2003). Yurydychna entsyklopediia: v 6 t. [Legal Encyclopedia: 6 vols.]. Kyiv: «Ukr.entsykl.», Vol. 5. [in Ukrainian].

19. Bouvier, J. (1856). A Law Dictionary, Adapted to the Constitution and Laws of the United States. $<$ https://legal-dictionary.the free dictionary.com/Personal+security $>$. [in English].

20. Lauterpacht, H. (1943). The Law of Nations, the Law of Nature and the Rights of Man, in Problems of Peace and War. Papers Read before the Society in the Year 1943, ed. British Institute of International and Comparative Law, Transactions of the Grotius Society. [in English]. 